\title{
ЗАСТОСУВАННЯ ПРИМУСОВИХ ЗАХОДІВ МЕДИЧНОГО ХАРАКТЕРУ В КРИМІНАЛЬНОМУ ПРОЦЕСІ
}

Туренко Д. В.

\begin{abstract}
У статті проведено ретроспективний аналіз положень законодавчих актів України, міжнародних правових актів, Рішень Європейського суду з прав людини, національного кримінального й кримінального процесуального законодавства й нормативно-правових актів стосовно підстав звернення з клопотанням слідчого, прокурора по закінченні досудового розслідування щодо можливого застосування судом примусових заходів медичного характеру. у дослідженні використано як емпіричну базу статистичні дані, практику правозастосовної діяльності слідчих, прокурорів, слідчих судаів, судових експертів та фахівців спеціалізованих медичних закладів, яка підтвердила актуальність порушених у статті проблемних та інших невирішених теоретичних і прикладних питань. У межах розгляду кримінального процесуального законодавства досліджуються питання як передумов, так $і$ процесуальний порядок у досудовому розслідуванні застосування примусових заходів медичного характеру. Розглянуто наукові дослідження з цих питань за останні роки, тенденції, а також наукові погляди провідних учених, що стосуються окремих питань відносно теми дослідження. Аргументовано викладено авторське бачення шляху розв'язання проблем і застосування примусових заходів медичного характеру в законодавчій, теоретичній і практичній діяльності. 3 метою вдосконалення правозастосовної практики надаються обгрунтовані роз'яснення й рекомендації в частині організаційних і процесуальних особливостей підготовки й проведення слідчих (розшукових) і негласних слідчих (розшукових) дій $і$ судово-психіатричних експертиз, що сприятимуть застосуванню судом у кримінальному процесі примусових заходів медичного характеру. Водночас акцентується увага на особливостях застосування спеціальних знань лікарів і відповідних фахівців і спеціалістів психіатрії, їх взаємодії у такій категорії кримінальних проваджень зі слідчими, прокурорами, слідчими суддями, судом. На підставі вищевикладеного сформульовано пропозиції щодо вдосконалення положень кримінального й кримінального процесуального законодавства, уточнення й доповнення поняттєвого апарату з питань, що безпосередньо стосуються уточнення й розширення процесуальних $і$ медичних підстав, порядку підготовки й проведення судових психіатричних та інших видів експертиз, а також з питань захисту прав, свобод і законних інтересів учасників кримінального провадження дослідженої категорії кримінальних проваджень.
\end{abstract}

Ключові слова: прокурор, стадія, учасники, доктрина, кримінальне провадження, судові інстанції, слідчий суддя, правовий інститут, експертиза, медичні проблеми, психіатрична допомога, форма закінчення, звернення, правові проблеми.

В статье проведен ретроспективный анализ положений законодательных актов Украины, международных правовых актов, Решений Европейского суда по правам человека, национального уголовного и уголовного процессуального законодательства и нормативно-правовых актов относительно оснований обращения в суд ходатайства следова-

Туренко Д. В., 2019 теля, прокурора по окончании досудебного расследования о возможном применении судом к лицу принудительных мер медицинского характера. В исследовании использованы как эмпирическая база статистические данные практики правоприменительной деятельности следователей, прокуроров, следственных судей, судебных экспертов и специалистов специализированных медицинских учреждений, которые подтвердили актуальность поднятых в статье проблемных и других нерешенных теоретических и практических вопросов. В рамках рассмотрения уголовного процессуального законодательства исследуются как вопросы предусловий, так и процессуальный порядок в досудебном расследовании оснований, что касается применения института принудительных мер медицинского характера. Рассмотрены научные исследования этих вопросов за последние годы, тенденции, а также научные взгляды ведущих ученых, которые касаются отдельных вопросов темы исследования. Аргументировано и изложено авторское виденье их решения и применения в законодательной, теоретической и практической деятельности. С челью усовершенствования правоприменительной практики автор обоснованно разъясняет и дает рекомендации в части организационных и процессуальных особенностей подготовки и проведения следственных (розыскных) и негласных следственных (розыскных) действий и судебно-психиатрических экспертиз, которые способствуют применению судом в уголовном процессе принудительных мер медицинского характера. Акцентируется внимание на особенностях применения специальных знаний врачей и соответствующих специалистов, а также специалистов по вопросам психиатрии, их взаимодействия в такой категории уголовных производств со следователями, прокурорами, следственными судьями, судом. На основании вышеизложенного сформулированы предложения по усовершенствованию положений уголовного и уголовного процессуального законодательства с уточнениями и дополнениями понятийного апnарата и вопросов, непосредственно касающихся уточнения и расширения процессуальных и медицинских оснований, порядка подготовки и проведения судебных психиатрических и других видов экспертиз, а также вопросов защиты прав, свобод и законных интересов участников уголовного производства в исследуемой категории уголовных производств.

Ключевые слова: следователь, прокурор, стадия, участники, доктрина, уголовное производство, судебные инстанции, следственный судья, правовой институт, экспертиза, медицинские проблемы, психиатрическая помощь, форма окончания, обращение, правовые проблемы.

The author of article provided a retrospective analysis of the provisions of the legislative acts of Ukraine, international legal acts, conclusions of the European Court of Human Rights, national criminal and criminal procedural legislation and normative legal acts on the grounds of the investigator's or the prosecutor's petition at the end of the pre-trial investigation of possible application compulsory medical measures by the court. During the study the author of the article used statistical data, the practice of law enforcement activities of investigators, pros- 
ecutors, investigative judges, court experts and specialists of specialized medical institutions as an empirical base. Information obtained by the author confirmed the relevance of the problematic and other unresolved theoretical and applied issues raised in the article. Within the framework of the criminal procedural legislation consideration, both the prerequisites and the procedural procedure in the pre-trial investigation of the grounds for applying the institute for the use of compulsory medical measures were investigated. The scientific researches on the raised questions in recent years, their tendencies, as well as the scientific views of the leading scientists concerning particular issues, concerning the topic of the research were considered. For this reason, the author's vision of their decision and application in legislative, theoretical and practical activity is substantiated and stated. The author, in order to improve the law enforcement practice, provided reasonable explanations and recommendations regarding organizational and procedural features of the preparation and conduct of investigative and secret investigative actions and forensic psychiatric examinations, which will facilitate the use of court in criminal proceedings compulsory medical measures. At the same time, the author paid attention to the peculiarities of application of special knowledge of doctors and relevant specialists in psychiatry, their interaction in such a category of criminal proceedings with investigators, prosecutors, investigating judges, the court.

Based on the above, the author of the article made some proposals for improving the provisions of criminal and criminal procedural legislation to clarify and to add the conceptual apparatus, on issues that directly relate to the specification and extension of procedural and medical grounds, the procedure for the preparation and conduct of forensic psychiatrists examinations, and rights, freedoms and legitimate interests of participants in criminal proceedings in such category of criminal cases.

Key words: investigator, prosecutor, stage, participants, doctrine, criminal proceedings, court instances, investigating judge, legal institute, examination, medical problems, psychiatric help, form of termination, appeal, legal problems.

Постановка проблеми та її актуальність. Сучасний кримінальний процес характеризується демократичними засадами, а не репресивними, як це було раніше. Це стосується й правового інституту застосування судом примусових заходів медичного характеру, що контролюється національним законодавством, міжнародними інституціями й системою правосуддя в країні загалом. За радянських часів існував поряд з іншими ще й такий вид репресій, коли Комітет державної безпеки колишнього СРСР практикував поміщення в психіатричні медичні заклади закритого типу осіб, які вели антирадянську агітацію й пропаганду, провина яких не була доказана або була доказана частково. 3 метою недопущення такого самочинства й порушень законності правоохоронними органами й судовими інстанціями введено ст. 151 Кримінального кодексу України (далі - КК України), яка закріплює норми про те, що невиконання принципів надання психіатричної допомоги, що супроводжується поміщенням до психіатричного закладу психічно здорової особи, тягне за собою кримінальну відповідальність [11]. 17 вересня 1987 р. Рада Європи прийняла резолюцію «Стосовно спрощення кримінального правосуддя» № 6R(87)18, відповідно до якої країни-учасниці повинні були переглянути кримінальне провадження у своїх країнах у бік гуманізації й удосконалення демократії та вжити заходів до розширення спрощеної процесуальної форми розслідування і його закінчення за кримінальним провадженням. Таким шляхом продовжує рухатись також Україна. Одним із напрямів спрощення закінчення досудового розслідування $є$ запровадження в кримінальний процес кримінальних проступків, що пролонговано до 1 липня 2020 р. Проблемні питання застосування примусових заходів медичного характеру не перестають бути актуальними не тільки для України, але й для багатьох інших країн. Це підтверджується й статистичними даними. Так, в Україні кількість осіб, до яких застосовувались примусові заходи медичного характеру, за останні роки зростає. Це підтверджується статистичними даними генеральної прокуратури України. Отже, до національних судів нашої країни направлялися клопотання про застосування примусових заходів медичного характеру, а саме: у 2013 р. направлено 1112; у 2013 р. - 940; у 2015 р. - 946; у 2016 р. - 866; у 2017 р. - 1100; у 2018 р. - 1070; за 9 місяців 2019 р. 281 [1; 2, с. 90-96]. Відповідно до статистики Всесвітньої організації охорони здоров'я $25 \%$ населення як розвинутих країн, так і країн, що перебувають на стадії розвитку, мають порушення психічного здоров'я [3, 45-54]. Крім цього, за результатами досліджень учених 20\% дітей та $8,9 \%$ молоді у світі страждають на психічні розлади [4, с. 5-9]. За висновками, які зробив російський учений В.Г. Назаренко, тенденція зростання кількості випадків скоєння злочинів цією категорією осіб характерна для Росії; водночас за різними оцінками серед осіб, що вчинили насильницькі злочини, було багато психопатів (від 30 до 60\%), а також осіб з пограничними психічними розладами [5, с. 39]. В інших країнах, наприклад у Квебеку (Канада) щороку від 350 до 400 осіб дорослої частини населення, що скоїли злочин, визнаються неосудними й відповідно непідсудними з причини психічної хвороби [6]. Згідно з даними Національного альянсу з психічних захворювань США близько 8\% усіх осіб, що перебувають у в'язницях та ізоляторах тимчасового утримування, страждають на тяжкі психічні захворювання, такі як шизофренія, і біполярні розлади [7]. Наведені дані підтверджують актуальність порушених у статті проблемних питань не тільки для України, але й для інших держав. Окрема частина психічно хворих осіб вчиняє злочини й потрапляє в кримінально-процесуальні відношення, що регулюються законодавством. Визначення правових і медичних заходів реагування на результати кримінальних дій такої категорії осіб з дотриманням їхніх прав і свобод стає непростою справою $з$ правової й медичної точок зору і покладається на службових осіб, які $є$ відповідальними за проведення досудового розслідування, процесуальне керівництво досудовим розслідуванням, проведення судово-психіатричних експертиз і розгляд у судових інстанціях кримінальних проваджень цієї категорії. Теоретична, законодавча й правозастосовна частина розглянутого направлення $\epsilon$ недосконалими й потребують подальшого дослідження, що свідчить про актуальність порушених у статті проблемних питань з цієї тематики.

Аналіз останніх досліджень і публікацій. Дослідження порушених у статті питань здійснювався в основному до проголошення Україною своєї незалежності й частково після. Ці питання досліджували такі вчені: С.Е. Абламський, Беклемищев, Г.І. Глобенко, А.Ю. Даниленко, Б.Н. Дердюк, І.В. Жук, І.І. Карташов, І.І. Книга, В.А. Колесник, О.О. Кочура, О.С. Крикунов, В.В. Саликова, Н.М. Сенченко, А.І. Ситникова, О.Г. Панчак, В.В. Печко, Л.Г. Татьянина, О.О. Торбас, Т.Г. Фоміна, С.Л. Шаренко, О.О. Юхно, О.О. Ямкова 
та інші. Після того як Україна стала незалежною державою, на рівні кандидатської дисертації ці питання досліджувалися С.Л. Шаренко (Харків, 2000 р.), О.О. Ямковою (Одеса, 2004 р.), І.В. Жук (Київ, 2009 р.), Н.Н. Книгою (Дніпропетровськ, 2009 р.), Б.Н. Дердюком (Одеса, 2012 р.). Дві дисертації були захищені у сфері кримінального процесу, решта - у галузі кримінального права, і то до набуття чинності Кримінального процесуального кодексу України (далі - КПК) 2012 р. Водночас наявні проблемні питання в кримінальному процесі, включно з новелами вказаного кодексу, оскільки теорія та практика спонукають до висунення багатьох дискусійних і проблемних питань, у тому числі й відносно застосування судом інституту примусових заходів медичного характеру, що вимагає ґрунтовного переосмислення й концептуального комплексного дослідження. Указане підтверджується також тим, що в чинному КПК України після 2012 р. було внесено понад 580 змін і доповнень, багато з яких залишаються не дослідженими.

Метою статті $\epsilon$ вивчення проблемних питань законодавчих i прикладних положень щодо можливості звернення на етапі (стадіі) закінчення досудового розслідування до суду з клопотанням про можливе застосування примусових заходів медичного характеру, а також напрацювання пропозицій і рекомендацій з удосконалення теорії, правозастосовної та законотворчої діяльності за порушеним питанням.

Виклад основного матеріалу. Слід зазначити, що становлення, розвиток i застосування примусових заходів медичного характеру в Україні як окремого процесуального інституту свідчить про неоднакове ставлення до правового й медичного становища психічно хворих осіб, що потрапили в кримінально-процесуальні відносини, та заходів, застосованих донихурізні історичні періоди. На теперішній час законодавство України, регламентуючи введення кримінальних проваджень щодо цієї категорії осіб, відповідає загальновизнаним принципам і нормам таких міжнародних актів, як Загальна декларація прав людини (1948р.), Конвенція про захист прав людини і основоположних свобод (1950 р.), Мінімальні стандартні правила поводження з в'язнями (1955р.), Міжнародний пакт про громадянські і політичні права (1966р.), Мінімальні стандартні правила Організації Об'єднаних Націй, що стосуються відправлення правосуддя щодо неповнолітніх («Пекінські правила») та інших актів. В Україні ці питання закріплені в Конституції, КК України, КПК України, Законі України «Про психіатричну допомогу» та інших законодавчих актах. Окрім цього, на виконання вказаних та інших міжнародних актів законодавець України, вдосконалюючи поняттєвий апарат, застосував коректніші назви спеціалізованих медичних закладів і в Законі України «Про внесення змін до деяких законодавчих актів України щодо надання психіатричної допомоги» від 14 листопада 2017 р. № 2205-УІІІ [8], змінив назву спеціалізованого медичного закладу 3 «психіатричного закладу» на «заклад з надання психіатричної допомоги». У науковій літературі структура правового інституту застосування примусових заходів медичного характеру, на думку окремих учених, або зовсім не наводиться, або розглядається фрагментарно чи обмежується її коротким описом [9, с. 35-37], що ми підтримуємо. Положення чинного КПК України, що регулює застосування примусових заходів медичного характеру на етапі досудового розслідування, включені в Главу 39 і деталізуються ст. ст. 503-511, а за судового розгляду відповідно ст. ст. 512-516. Водночас попри наявність такої кількості статей у КПК України [10] у них не надається законодавчого визначення поняття примусових заходів медичного характеру - воно визначене лише в КК України. У ст. 92 цього кодексу закріплено, що примусовими заходами медичного характеру $є$ надання амбулаторної психіатричної допомоги, поміщення особи, що вчинила суспільно небезпечне діяння, яке підпадає під ознаки дій, передбачених Особливою частиною КК України, у спеціальний лікувальний заклад з метою іï обов'язкового лікування, а також запобігання вчиненню ним суспільно небезпечних діянь [11]. Неможливо не підтримати в цьому питанні думку П.А. Колмакова про те, що доктринальні визначення цього процесуального інституту достатньо складні й громіздкі, оскільки окремі вчені намагаються включити в дефініцію також інші характеристики примусових заходів [12, с. 17]. Сьогодні в науці ведеться дискусія відносно необхідності визначення названих понять. На думку Г.С. Саркісова, значна кількість понять говорить про нечітке, а іноді й спірне розуміння понять, що напевно $є$ наслідком недостатнього розроблення цієї проблеми [13, с. 40-41]. Ми підтримуємо це твердження, що підкреслює актуальність порушеного питання. Для більшої аргументації варто навести наукову позицію Ю.В. Орлова, який визначив, що висувається гостра проблема в міжгалузевій, міжсистемній систематизації наявних знань, їх синхронізації, адаптації з громадською вимогою для розв'язання комплексних завдань [14, с. 12-13]. У цій дискусії також слід підтримати наукову позицію А.І. Ситнікова про те, що відсутність правової дефініції не відповідає правилам юридичної техніки конструювання складних інститутів. Для приведення положень кримінального процесуального законодавства у відповідність до правил конструювання кримінально-правових інститутів необхідно розробити законодавче визначення поняття «примусових заходів медичного характеру», що дасть можливість зробити наступні нормативні приписи не такими громіздкими, викласти матеріал більш ефективно, економно й упорядковано, а також підвищити соціальну цінність кримінально-правових норм, що регулюють застосування заходів медичного характеру стосовно особливої категорії осіб [15, с. 135-136]. У ст. 92 КК України вперше закріплено цілі застосування примусових заходів медичного характеру, які узагальнено можна означити так: 1) застосування примусових заходів медичного характеру $є$ обов' язковим незалежно від волі особи, до якої ïx застосовано; 2) запобігання вчиненню суспільно небезпечних діянь з боку осіб, які страждають на психічні розлади, що становлять небезпеку як для самого хворого, так і для інших осіб. Відповідно ст. 93 КК України визначено осіб, до яких можуть застосовуватися примусові заходи медичного характеру, а саме: 1) обов'язкове лікування неосудних осіб, які вчинили суспільно небезпечне діяння; 2) обов' язкове лікування обмежено осудних осіб, які вчинили суспільно небезпечне діяння; 3) лікування осудних осіб, які були осудними в момент вчинення злочину, але захворіли на психічне захворювання після вчинення злочину до ого- 
лошення вироку чи під час відбування покарання. На підставі вищевказаного й наявності дискусії з цих питань, ми пропонуємо таку дефініцію: примусові заходи медичного характеру - це заходи державного примусу у формі різних лікувально-реабілітаційних заходів, застосованих судом у межах кримінального процесу відносно осіб з різними психічними розладами, які вчинили суспільно небезпечне діяння й направлені на лікування, за суворого дотримання прав, свобод і законних інтересів таких осіб. Прийняття рішення про застосування примусового лікування особи $\epsilon$ не обов'язком, а правом суду. Примусові заходи медичного характеру мають подвійне значення. 3 одного боку це заходи примусу, тобто юридичні заходи, а з іншого - це заходи медичні, оскільки вони складаються з діагностичного дослідження, лікування, клінічного спостереження, проведення реабілітаційних заходів працівниками органів охорони здоров'я. Указані заходи не можна розцінювати як покарання, оскільки вони істотно й принципово відрізняються від нього своєю ціллю і методами, однак водночас $\epsilon$ заходами примусу, тому що призначаються й припиняються тільки судом незалежно від згоди хворого чи його законних представників. Окрім цього примусові заходи медичного характеру застосовуються до психічно хворих осіб, які представляють суспільну небезпеку внаслідок психічного розладу та вчинили злочин або захворіли на таке захворювання вже після його вчинення або під час відбування покарання. Заходи медичного характеру не мають кримінально карних ознак, а також не вважаються судимістю та не переслідують ціль виправлення. До особи, яка направлена на примусове лікування, не може бути застосована амністія, така особа не може бути помилувана. Ініціювати й реалізувати положення чинного законодавства в частині забезпечення медичної складової й проведення необхідних судово-психіатричних експертиз слідчий, прокурор, суддя можуть за допомогою залучення як спеціалістів і консультантів лікарів відповідних спеціальностей на підставі ст. 71 КПК України, а також лікарів-експертів відповідно до ст. 69 цього ж кодексу. Для примусового лікування цих та інших осіб вони можуть залучати лікарів - спеціалістів інших галузей як осіб, що мають спеціальні знання й практичні навички, зокрема й для проведення інших видів експертиз. Велике й принципове значення мають підготовка, проведення, використання й оцінка матеріалів і висновків судово-психіатричних експертиз для вирішення слідчим чи прокурором питання про необхідність направлення клопотання до суду про застосування примусових заходів медичного характеру. Варто наголосити на необхідності суттєвої підготовки до проведення таких експертиз, що вимагає значної кількості відповідних документів, зокрема довідки про перебування (або відсутність) на психіатричному обліку i, якщо так, відомостей і результатів діагностики; медичних документів та історії хвороби щодо лікування психічного захворювання й проведеного лікування; характеристики з місця роботи, навчання й проживання; протоколів допиту лікаря (лікарів), що здійснював лікування, близьких родичів і членів сім'ї, друзів, знайомих, керівників і колег (по роботі чи навчанню) та інших осіб, з якими спілкувалася особа, що направляється на психіатричну експер- тизу. Відносно військовозобов'язаних має надаватися військовий квиток або медичні й інші документи, що підтверджують причини звільнення від військового обов'язку або непридатність до військової служби, та інші документи на запити членів комісії, що проводять судово-психіатричну експертизу. Необхідним критерієм і умовою для включення до складу відповідних судово-психіатричних експертиз $\epsilon$ об'єктивний підхід, який забороняє залучати до них лікарів, що здійснювали лікування такої категорії осіб, або лікарів з того медичного закладу, в якому лікувалася направлена на таку експертизу особа. Міжнародна спільнота опікується порушеними в статті проблемними питаннями. Зокрема, Європейський суд з прав людини (далі - ЄСПЛ) стоїть на сторожі дотримання прав і свобод людини, особливо уважно розглядає справи по скаргах такої категорії кримінальних проваджень. Так, у справі «Гайдн проти Германії (Haidn v. Germani), заява № 6587/04, рішення від 13 січня 2011 р., кінцеве рішення від 13 травня 2011 р., а також у справі «X. проти Фінляндії (X. v. Finland) №34806/04, рішення від 3 липня 2012 р. констатовано, що для досягнення завдань підпункту «е» п. 1 ст. 5 Конвенції про захист прав людини і основоположних свобод (1950р.) особа може бути позбавлена волі (заарештована) або затримана як душевнохвора для проведення психіатричного обстеження тільки у випадку наявності трьох мінімальних умов: 1) повинно бути достеменно встановлено, що ця особа $є$ психічно хворою, компетентним органом на підставі об'єктивної медичної експертизи; 2) психічний розлад повинен мати стадію, яка потребує обов'язкової ізоляції; 3) продовження ізоляції залежить від збереження такого психічного стану. Водночас суд конкретизує умови утримування під вартою особи або іiі затримання як душевнохворої та вважає ці умови законними для досягнення завдань підпункту «е» п. 1, якщо таке утримування під вартою здійснюється в лікарні, клініці або в іншому відповідному лікувальному закладі [16, с. 865-869]. Ці рішення ЄСПЛ доповнюють й уточнюють національну законодавчу базу й практику слідчих, прокурорських і судових органів з порушених у цій статті проблемних питань, а також сприяють удосконаленню теоретичної й прикладної частин кримінального процесу України. На підставі даних щодо тенденції зростання кількості психічно хворих, які вчиняють суспільно небезпечні діï, питання застосування примусових заходів медичного характеру має подальшу перспективу в наукових, прикладних дослідженнях, а також у правозастосовній діяльності працівників правоохоронних органів, медичних працівників і судових експертів як в Україні, так і в багатьох інших країнах.

Висновки. Правовий інститут застосування примусових заходів медичного характеру, що закріплений у кримінальному процесі України, також $\epsilon$ й у більшості галузей кримінального права й процесу інших країн. Дослідження можливості й підготовки на стадії досудового слідства клопотань про можливе застосування судом примусових заходів медичного характеру як однієї з форм закінчення досудового розслідування свідчить про те, що в цьому напрямі існують проблемні питання, які $\epsilon$ актуальними не тільки для України, але й для інших країн. Це підтверджують результати наукових досліджень цієї проблематики, а також наявність 
законодавчої й нормативної бази, медичної, слідчої, прокурорської, експертної й судової практики, у тому числі наведені статистичні дані й тенденції, установлені під час розслідування й судового розгляду такої категорії кримінальних проваджень. У ході наукового дослідження цього напряму встановлено, що в чинних КК і КПК України мають місце деякі недоліки, відсутність або неточність окремих понять, неповне викладення цілей і задач, наявні проблемні питання, які слід закріпити в законодавчому порядку, використовуючи також досвід інших країн. У зв'язку з цим автором внесено пропозиції, що направлені на вдосконалення чинного законодавства, теоретичних і практичних питань досліджуваного напряму, що мають перспективу в кримінальному судочинстві України, криміналістиці, судовій експертології та психіатричній медицині. Порушені питання не $\epsilon$ остаточними й підлягають окремому дослідженню або науковому вивченню.

\section{Література}

1. Єдиний звіт про кримінальні правопорушення за 2013-2019 рр. Розділ 1. Сайт «Генеральної прокуратури УкраїHи». URL: https://www.gp.gov.ua/ua/statinfo.html bolfotouh.

2. Проблемы обеспечения и реализации прав психически больных лиц в уголовном производстве Украины / О.0. Юхно и др. Geogian Medical News. № 1 (286), 2019. C. 90-96.

3. Attitudes toward mental illness, mentally ill persons, and help-seeking among the Saudi public and sociodemographic correlates / Almutairi A.F. et al. Psychology Research and Behavior Management. Vol. 12, 2019, pp. 45-54.

4. Шмідт Л. Психічне здоров'я дітей і підлітків. HeŭpoNEWS. 2016. № 8 (82). C 5-9.

5. Назаренко Г.В. Правовая и криминологическая значимость уголовно-релевантных психических состояний. Орел. 2002. С. 39.

6. When a person suffering from a mental disorder commits an offence. Justice and Mental Health in Quebec.
Affiliated with McGill University. A WHO/PAHO Collaborating Centre for Research and Training in Mental Health. URL: http://www.douglas.qc.ca/info/committing-an-offence.

7. Aguide to mental illness and the criminal justice system. National Alliance on Mental Illness Department of Policy and Legal Affairs. URL: http://www.pacenterofexcellence. pitt.edu/documents/Guide_to_Mental_Illness_and_the_ Criminal_Justice_System_NAMI.

8. Про внесення змін в окремі законодавчі акти України про надання психіатричної допомоги : Закон України від 14 листопада 2017 р. № 2205-VIII. Голос України. 2017. № 231.

9. Назаренко Г.В. Принудительные меры медицинского характера : учебное пособие. Москва. 2003. С. 35-37.

10. Кримінальний процесуальний кодекс України : станом на 25 липня 2019 р. Харків : Право. 2019. 412 с.

11. Кримінальний кодекс України : чинне законодавство зі змінами та доповн. на 16 вересня 2019 р. Київ : Алерта. 2019. 214 с.

12. Колмаков П.А. Проблемы правового регулирования мер медицинского характера. Сыктывкар. 2001. С. 17.

13. Саркисов Г.С. Социальная система предупреждения преступности. Ереван : Айстан. 1975. 159 с.

14. Орлов Ю.В. Політико-кримінологічна теорія протидії злочинності : монографія. Харків : Діса плюс. 2016. 656 c.

15. Ситников А.И. Принудительные меры медицинского характера: законодательная техника. Вестник Омского университета. Серия «Право». 2008. №4 (17). С. 135-147.

16. Кримінальний процесуальний кодекс України з постатейними матеріалами практики Європейського суду з прав людини /За заг. ред. А.В. Столітнього. 2-ге вид. переробл. та доповн. Харків : Право. 2019. 952 с.

Туренко Д. В., ад'юнкт Харківського національного університету внутрішніх справ 